\title{
ISLAM PROGRESIF VERSI ABDULLAH SAEED (Ikhtiar Menghadapi Problem Keagamaan Kontemporer)
}

\author{
Fathurrosyid \\ (Fakultas Ushuluddin INSTIKA Guluk-Guluk Sumenep Madura, \\ Email: fathurrosyid090381@gmail.com)
}

\begin{abstract}
Abstrak:
Tulisan ini membedah gagasan Abdullah Saeed tentang Islam Progresif. Menurutnya, Muslim progresif adalah seseorang atau kelompok yang meyakini bahwa perubahan sosial-keagamaan era kontemporer tidak akan menemukan solusi jika metodologinya berupa piranti paradigma lama, tanpa dilakukan proses integratifinterkonektif dengan disiplin keilmuan kontemporer. Sebab, terdapat perbedaan substantif antara problem kontemporer dengan problem di masa sebelumnya. Berkaitan dengan hal ini, Saeed menawarkan tujuh metodologi menafsir ulang teks-teks keagamaan. Pertama, memberikan atensi pada konteks dan dinamika sosio-historis. Kedua, menyadari bahwa ada beberapa topik yang tidak dicakup oleh alQur`an karena waktunya belum tiba pada saat turunnya. Ketiga, menyadari bahwa setiap pembacaan atas kitab suci harus dipandu oleh prinsip kasih sayang, keadilan dan kejujuran. Keempat, mengetahui bahwa al-Qur`an mengenal hirarki nilai-nilai. Kelima, mengetahui bahwa dibolehkan berpindah dari satu contoh yang konkrit pada generalisasi. Keenam, harus hati-hati dalam menggunakan teks lain dari tradisi klasik, khususnya yang berkaitan dengan otentisitasnya. Ketujuh, fokus utama pada kebutuhan Muslim kontemporer.
\end{abstract}

Abstract:
This article dissects the Abdullah Saeed's notion on Progressive Islam.
According to him, progressive Moslem is someone or a group that
believes that the socio-religious changes in the contemporary era will
not find a solution if the old paradigm of the methodology in the form
of devices, without the integrative-interconnective process performed
with contemporary scientific disciplines. Therefore, there is a
substantive difference between the contemporary problems and the
classical problems. In this regard, Saeed offers seven methodologies
reinterpret religious texts. First, give attention to the context and
dynamics of the socio-historical. Second, realize that there are some

al-1hkâm Vol.10 No.2 Desember 2015

DOI: http:/ /dx.doi.org/10.19105/ihkam.v10i2.722 
Fathurrosyid

topics that are not covered by the Qur because the time has not arrived at the time of the decline. Third, realize that every reading of the scriptures should be guided by the principles of compassion, fairness and honesty. Fourth, know that the Qur recognize a hierarchy of values. Fifth, knowing that it is allowed to move from one concrete example of the generalization. Sixth, should be careful in using other texts of the classical tradition, especially with regard to its authenticity. Seventh, the main focus on the needs of contemporary Moslems.

\section{Key Words:}

Islam Progresif, Abdullah Saeed, Problem Kontemporer, Sosiohistoris

\section{Pendahuluan}

Al-Qur`an diyakini umat Muslim tidak hanya sebagai guidance ${ }^{1}$ atau hudan li al-nâs dan rahmatan li al- alamîn semata, tetapi juga menjadi inspirator ${ }^{2}$ lahirnya gerakan-gerakan keagamaan dan pemikiran Islam dalam rangka untuk mencari Islam autentik. Dalam konteks ini, maka lahirlah "terminologi-terminologi" kelompok dari berbagai varian yang kesemuanya dilabelkan pada Islam misal, Islam liberal, Islam post-tradisionalis dan Islam salafi. Para peneliti gerakan pemikiran Islam di Indonesia, baik peneliti dari Indonesia sendiri seperti Bahtiar Effendy dan Fachry Ali, ${ }^{3}$ Syafi'i Anwar, ${ }^{4}$ dan Deliar

1 Dalam konteks semacam ini, al-Qur`an seringkali di berbagai tempat atau surat memproklamasikan dirinya sebagai "hudan li al-nâs", sebut saja misalnya, di awal permulaan surat al-Baqarah, al-Qur`an dengan tegas menyatakan sebagai hudan li almuttaqîn. Lihat Q.S al-Baqarah 2:2.

2 Kondisi ini sebenarnya juga dipicu dan dipacu adanya rasa kuriositas ummat Islam yang ingin selalu "mengkonsumi" dan menjadikan al-Qur`an sebagai pedoman hidup, bahkan legitimasi bagi tindakan dan perilakunya yang dalam terminologi filsafat etika, -meminjam istilah George Fadlau Haurani- disebut dengan theisticsubjectivism; yaitu sistem nilai yang merujuk pada kitab suci. Lihat selengkapnya; G. F. Houroni, Reason and Tradition in Islamic Ethic (Cambridge: University Press Cambridge, 1985), 158-149.

${ }^{3}$ Fachry Ali dan Bahtiar Effendy, Merambah Jalan Baru Islam, Rekonstruksi Pemikiran Islam Masa Orde Baru, (Bandung: Mizan, 1986).

4 M. Syafi'i Anwar, Pemikiran dan Aksi Islam Indonesia, Sebuah Kajian tentang Cendikiawan Muslim Orde Baru, (Jakarta: Paramadina, 1995). 
Noer, ${ }^{5}$ maupun peneliti asing seperti Howard M. Federspiel, ${ }^{6}$ Greg Barton, 7 dan Kamal Hassan ${ }^{8}$, senantiasa bertitik tolak dari kategori dasar tradisionalis dan modernis dalam memetakan gerakan pemikiran Islam, meskipun dengan penjelasan yang bervariasi.

Dua tipologi dasar tersebut kemudian berkembang menjadi varian-varian baru. Dari tipologi tradisionalis kemudian berkembang menjadi tipologi neo-tradisionalis yang mencoba melakukan pembaruan atas tradisi seperti dilakukan Abdurrahman Wahid, dan post-tradisionalis yang melakukan kritisisme atas tradisi, mengadopsi metode pemikiran modern dengan tetap menggunakan tradisi sebagai basis transformasi. Sementara dari kelompok modernis lahir neo-modernisme yang diwakili tokoh seperti Nurcholish Madjid dan Syafi'i Ma'arif yang kemudian bermetamorfosis menjadi gerakan Islam liberal. Namun kelompok ini juga memunculkan varian fundamentalis dan neo-fundamentalis yang cenderung memahami ajaran Islam secara tekstual.

Dari beberapa varian di atas, meskipun substansinya tidak jauh berbeda dengan terma-terma lain, seperti Islam inklusif, ${ }^{9}$ Islam transformatif, 10 dan Islam liberal, kehadiran Islam progresif (progressive Islam) merupakan istilah baru dalam kajian Islam kontemporer yang digunakan oleh para akademisi dan aktivis sejak beberapa tahun belakangan ini untuk memberikan label kepada pemahamanpemahaman dan aksi-aksi umat Islam yang memperjuangkan penegakan nilai-nilai humanis, seperti pengembangan civil society, demokrasi, keadilan, kesetaraan jender, pembelaan terhadap kaum tertindas dan pluralisme.

\footnotetext{
5 Deliar Noer, Gerakan Modern Islam di Indonesia 1900-1942, (Jakarta: LP3ES, 1996). Buku ini dicetak kali pertama tahun 1980, hingga 1996 sudah dicetak ulang delapan kali.

6 Howard M. Fiderspiel, Persatuan Islam, Pembaruan Islam Indonesia Abad XX, (Yogyakarta: Gadjah Mada University Press, 1996).

7 Charlez Kuzman, Islam Liberal, dan Greg Barton, Gagasan Islam Liberal di Indonesia (Jakarta: Pustaka Antara, 1999).

8 Kamal Hassan, Muslim Intellectual Response to New Order Modernization in Indonesia, (Kuala Lumpur: Dewan Bahasa, 1980).

${ }_{9}$ Alwi Shihab, Islam Inklusif; Menuju Sikap Terbuka dalam Beragama, (Bandung: Mizan, 1999).

10 Moeslim Abdurrahman, Islam Tranformatif, (Jakarta: Pustaka Firdaus, 1997).
} 
Pandangan dan aksi Islam progresif, menurut Omid Safi, sebenarnya merupakan kelanjutan dan kepanjangan dari gerakan Islam liberal yang muncul sejak kurang lebih seratus lima puluh tahun yang lalu, di satu sisi. Namun, di sisi lain corak progresif muncul sebagai bentuk ungkapan ketidakpuasan terhadap gerakan Islam liberal yang lebih menekankan pada kitik-kritik internal terhadap pandangan dan prilaku umat Islam yang tidak atau kurang sesuai dengan nilai-nilai humanis. Sementara itu, kritik terhadap modernitas, kolonialisme dan imperialisme justru tidak mendapatkan porsi perhatian yang cukup besar dari gerakan Islam liberal.11

Kenyataan inilah yang memberikan inspirasi terhadap munculnya pemahaman dan aksi Islam progresif. Mereka memberikan perhatian yang seimbang antara kritik internal dan kritik eksternal. Kritik internal terhadap tradisi pemikiran sebagian umat Islam yang tidak menitikberatkan pada aspek-aspek kehidupan humanis memposisikan gerakan Islam progresif pada gerakan modernis, namun pada waktu yang bersamaan ia juga merupakan gerakan "postmodernis", karena ia juga bersikap kritis terhadap modernitas yang bertentangan dengan nilai-nilai keadilan sejati dan kemanusiaan. Cara pandang, kritik dan aksi Islam progresif semuanya hendaknya berorientasi kepada kemajuan. Atas dasar hal ini pemikiran tersebut disebut dengan istilah "progresif". ${ }^{12}$ Abdullah Saeed termasuk salah-satu pemikir Islam kontemporer yang peduli dengan proyek dan gagasan progresif ini.

Berdasarkan fenomena di atas, penelitian ini mengungkap dan menyingkap dua hal; Pertama, apa saja karakteristik Islam progresif perspekif Abdullah Saeed. Kedua, bagaimana metodologi dan cara kerja model ijtihad Islam progresif perspekif Abdullah Saeed. Ketiga, Di mana posisi pemikiran Abdullah Saeed dengan pemikiran tokoh lainnya. Pertanyaan tersebut, tentu saja akan mengelaborasi lebih jauh tentang ikhtiar menghadapi problem keagamaan di era kontemporer ini menurut cara kerja ijtihad Islam progresif, sehingga dari model ini diharapkan dapat diketahui "ruang kosong" serta posisi gerakan

11 Sahiron Syamsuddin, Islam Progressif dan Upaya Pembumiannya di Indonesia. nahdliyinbelanda.wordpress.com. (Diakses pada tanggal 25 Nopmeber 2015).

12 Farish A. Noor, Islam Progresif: Peluang, Tantangan, dan Masa Depannya di Asia Tenggara, terj. Moch. Nur Ichwan dan Imron Rosyadi, (Yogyakarta: SAMHA, 2006), 23. 
tersebut dari gerakan-gerakan pemikiran Islam lainnya yang selama ini eksis dalam pergualatan pemikiran keislaman kontemporer.

\section{Islam Progresif; Potret Sejarah Perjalanan Gerakan Keislaman}

Kehadiran suatu pemikiran, gerakan atau gebrakan baru dalam wacana keberagamaan pasti mengalami lika-liku sejarah tersendiri. Karena itu, wajar jika kemudian potret sejarah gerakan Islam progresif tidak jauh berbeda dengan sejarah perjalanan gerakan Islam lainnya. Hal ini tampak ketika ide-ide cerdas untuk menggulirkan wacana Islam progresif mengalami dan bertemu dengan batu sandungan yang teramat besar. Kehadiran gerakan ini, menuai aksi pro-kontra di masyarakat, baik terkait dengan definisi, konsep dan teori yang diusungnya mupun pada tataran sosialisasinya.

Dalam wilayah definisinya saja, terma Islam progresif antara satu pakar dengan yang lain mempunyai perbedaan yang sangat tajam, meski secara substantif adalah sama-sama mempunyai ide yang mengusung kemajuan dan pembaharuan. Sebut saja misalnya, Syed Hussein Alatas menjelaskan bahwa terma Islam progresif tidak menyiratkan abstraksi ataupun reduksi dari totalitas Islam, melainkan sebuah istilah yang mengindikasikan bahwa Islam itu memang sejatinya bersifat progresif.

Watak asli Islam seperti itu yang sesungguhnya akan diangkat ke permukaan. Sementara itu, Alparsalan Acikgenc, dari Fatih University Turki, menyatakan bahwa Islam progresif adalah Islam yang menawarkan keseimbangan antara mysterious and the rational aspects of human nature. Definisi lainnya adalah yang dikemukakan oleh Abdullah Saeed bahwa Islam progresif merupakan salah satu dari sekian banyak aliran pemikiran Islam kontemporer yang berupaya untuk incorporate the contexts and the needs of modern Muslims yang pada akhirnya sesungguhnya menuju "want to act to preserve the vibrancy and variety of the Islamic tradition."13

Kecuali itu, konsep dan terminologis Islam progresif-pun juga mendapat kritik keras dan pedas dari berbagai kalangan, semisal

13 Ahmad Imam Mawardi, "Muslim Progresif dan Ijtihadi Progresif dalam Pandangan Abdullah Saeed", dalam Tolhatul Choir, Islam dalam Berbagai Pembacaan Kontemporer, (Yogyakarta: Pustaka Pelajar, 2009), 521. 
Chandra Muzaffar dan Ashgar Ali Engineer. Kedua tokoh tersebut, bagian dari representasi tokoh lain yang teramat keberatan dengan labelisasi progresif. Mudzaffar, misalnya tidak setuju dengan labelisasi Islam dengan label progresif, konservatif atau liberal karena label-label ini cenderung membatasi kemampuan seorang pembicara (juru dakwah) untuk berhubungan dengan audiennya yang disebabkan oleh pembedaan dan penggolongan masyarakat muslim. Sementara itu, gagasan risistensi yang diproklamasikan oleh Ashgar terhadap terminologi progresif disebabkan Islam itu secara inherent sudah bersifat progresif, membebaskan dan bersifat revolusioner. Baginya, lebih baik mengkatagorikan Islam secara periodik seperti kajian Islam pada masa modern dari pada berbicara tentang Islam modern.

Hampir sama dengan Ashgar, Syed Farid Alatas menyoroti dengan keras istilah Islam progresif ini. Ia menyatakan bahwa istilah ini tidak perlu digembar-gemborkan karena menyiratkan adanya Islam yang tidak progresif. Lebih jauh lagi, istilah ini berkonotasi memiliki hubungan intim dengan suatu label yang disebut dengan Islam liberal, berkaca pada pengalaman cendikiawan-cendikiawan yang ada di Mesir dan Indonesia. ${ }^{14}$

Kalaupun fenomena di atas menunjukkan bahwa pemikirpemikir dan penggiat ilmu keislaman di atas tidak setuju dalam hal teknis, tetapi sejatinya mereka sepakat dalam hal perlunya penafsiran ulang terhadap teks-teks keagamaan yang tampak bertentangan nilainilai humanis tersebut. Karena itu, untuk membumikan pandanganpandangan progresif, gerakan Islam progresif telah dilembagakan dan di-"proklamirkan" untuk pertama kalinya oleh para intelektual dan aktivis Muslim yang hidup di Amerika Utara pada tanggal 15 November 2004 dengan nama Progressive Muslim Union (PMU; Persatuan Muslim Progresif). Mereka yang tergabung dalam organisasi ini memiliki keahlian keilmuan yang beragam, ${ }^{15}$ termasuk di antaranya adalah Abdullah Saeed.

\footnotetext{
14 Ibid.,

15 Syamdsuddin, Islam Progresif. 


\section{Biografi, Karier Intelektul, dan Produktivitas Pemikiran Abdullah Saeed}

Abdullah Saeed adalah seorang profesor Studi Arab dan Islam di Universitas Melbourne, Australia. Beliau lahir di Maldives, sebuah pulau yang kemudian membentuk diri menjadi Negara Republik. Negara ini terletak di bagian utara lauatan India, kira-kira $500 \mathrm{~km}$ atau 310 mil Barat Daya India. Penduduk yang menghuni di negara ini bersala dari Srilanka, India dan Arab. Bahasa yang mereka gunakan adalah Bahasa Divehi yang berasal dari Srilanka. Secara umum penduduk Negara ini memeluk agama Islam. ${ }^{16}$

Pada tahun 1977, Saeed hijrah ke Arab Saudi untuk menuntut ilmu di sana. Di Arab Saudi, ia belajar Bahasa Arab dan masuk beberapa lembaga pendidikan formal, di antaranya Institut Bahasa Arab Dasar (1977-1979) dan Bahasa Arab Menegah (1979-1982) serta Universitas Islam Saudi Arabia di Madinah (1982-1986). Tahun berikutnya Saeed meninggalkan Arab Saudi untuk belajar di Australia. Di negeri kanguru ini, Saeed memperoleh beberapa gelar akademik. Pada tahun 1993, dia diangkat sebagai asisten dosen pada jurusan bahasa-bahasa Asia dan antropologi di Universitas Melbourne. Kemudian pada tahun 1996, ia menjadi dosen senior pada perguruan tinggi yang sama dan menjadi anggota asosiasi profesor pada tahun 2000. Pada tahun 2003, Saeed berhasil meraih gelar profesor dalam bidang studi Arab dan Islam. Sejak karier mengajarnya di Universitas Melborune pada tahun 1990-an, Abdullah Saeed telah melakukan peletakan pondasi studi islam di universitas tersebut khususnya, dan di Australia pada umumnya. Sejak itu, program studi Islam berkembang pesat mulai dari program studi strata satu (S1) sampai pada program doktoral.

Dilihat dari produk-produk pemikirannya yang sudah terpublikasikan, Abdullah Saeed adalah seorang penulis produktif. Indikator kongkrit ke arah tersebut adalah terlihat dari begitu banyak karya tulis ilmiah yang dilahirkannya. Beliau dikenal sebagai sarjana yang produktif, sehingga wajar jika banyak melahirkan karya-karya ilmiah, baik dalam bentuk tulisan lepas, makalah maupun karya ilmiah berupa buku yang telah dipublikasikan.

${ }^{16}$ Lebih jelasnya baca pada www.abdullahsaeed.org. 
Berikut ini karya-karya Abdullah Saeed, di antaranya; Pertama, buku pengantar tentang bagaiman bergaul dengan al-Qur'an yang diberi judul, The Qur: an Introduction, diterbitkan di London dan New York oleh Routledge tahun 2008. Kedua, buku yang memberikan porsi tentang gagasan pemikiran keislaman berjudul, Islamic Thoght: An Introduction diterbitkan di London dan New York oleh Routlede tahun 2006. Ketiga, buku yang berbicara banyak tentang metodologi interpretasi terhadap al-Qur`an dengan judul, Interpreting The Qur; Towards A Contemporary Approach, London dan New York oleh Routledge tahun 2006. Keempat, sebagai editor buku tentang Contemporary Approachs to Qur In Indonesia yang terbitkan tahun 2005.

\section{Problem Literalistik dan Kegelisahan Akademik Abdullah Saeed}

Abdullah Saeed adalah seorang cendekiawan muslim yang mempunyai latar belakang pendidikan bahasa dan sastra Arab serta studi Timur Tengah yang baik dan profesional. Kualifikasi, kompetensi, serta disiplin keilmuan yang selama ini digelutinya mampu menghantarkan dirinya menjadi seorang intelektual yang humanis dalam membela hak-hak orang lain. Kecuali itu, beliau juga merupakan tokoh yang mampu melihat secara kritis-dialektis dalam setiap problem keagamaan yang sedang dihadapi pada zamannya. Kombinasi institusi pendidikan yang selama ini diikutinya, yaitu pendidikan di Saudi Arabia dan Australia, menjadikan diri beliau sebagai sosok yang kompeten untuk menilai dua dunia, Barat dan Timur, secara objektif dan proporsional.

Sebagaimana telah dijelaskan dalam biografi, Abdullah Saeed merupakan salah-satu pemikir Islam kontemporer. Ketika dirinya melihat fenomena terjadinya perubahan yang sangat mendasar dalam segala aspek dan sendi kehidupan manusia, maka menyikapinya secara kritis, objektif dan inovatif adalah menjadi sesuatu yang sangat mendesak secara mutlak untuk segera dicarikan dan dicairkan solusinya. Dalam konteks persoalan umat Islam, terdapat persoalan dalam memahami al-Qur`an dan Hadits di tengah kompleksitas problem kontemporer saat ini.

Menurut Ignaz Goldziher, ${ }^{17}$ setiap orang maupun kelompok akan mencari justifikasi dan legitimasi dalam kitab sucinya, baik al-

17 Ignaz Goldziher, Mazhâhib al-Tafsîr al-Islâmî, (Mesir: Maktabah al-Khaniji, 1955), 3. 
Qur'an, Hadits, maupun kitab-kitab yang dikonstruksi oleh generasi awal, dan ia akan mendapatkan pandangan tertentu dari apa yang dicarinya. Namun persoalan menjadi krusial bila apa yang dicarinya belum -atau malah tidak- mendapatkan jawaban lantaran keterbatasan "teks suci" untuk berdialektika dan bernegosiasi dengan perubahan besar kekinian. Menurut Abdullah Saeed sebagaimana dikutip oleh M. Amin Abdullah, isu besar kekinian antara lain terkait dengan globalisasi, migrasi penduduk, kemajuan sains dan teknologi, eksplorasi ruang angkasa, penemuan-penemuan arkeologis, evolusi dan genetika, pendidikan umum dan tingkat literasi.

Di samping itu semua adalah bertambahnya pemahaman dan kesadaran tentang pentingnya harkat dan martabat manusia (human dignity), perjumpaan yang lebih dekat antar umat beragama (greater inter-faith interaction), munculnya konsep negara-bangsa yang berdampak pada kesetaraan dan perlakuan yang sama kepada semua warga negara (equal citizenship). Begitu juga isu perjuangan dan kesetaraan gender. ${ }^{18}$

Melihat fenomena semacam ini, maka para pemikir muslim kontemporer mencoba melakukan re-evaluasi, reformulasi dan rekonstruksi terhadap wacana keilmuan Islam yang ada selama ini. Proses ini menjadi urgen dalam rangka untuk menjembatani adanya gap dan inkonsistensi antara Islam dan realitas yang terjadi. Inkonsistensi antara idealita dan realita tersebut dilakukan tidak hanya dengan cara melakukan reinterpretasi terhadp teks-teks yang ada, tetapi lebih jauh produks yang digagas oleh generasi awal tersebut dikawinkan dan didialektikan secara integratif-interkonektif dengan perangkat metodologi disiplin keilmuan modernkontemporer.

Upaya integratif-interkonektif perangkat metodologis di atas dilakukan agar Islam tidak menjadi agama yang menjulang tinggi di atas langit (theocentris), tetapi betul-betul menjadi agama yang responsif dengan realitas kehidupan dibumi (antropochentris). Islam diidealisasikan tidak menjadi agama yang hanya mengawang-

18 M. Amin Abdullah, "Reaktulisasi Islam yang Berkemajuan; Agenda Strategis Muhammadiyah Ditengah Gerakan Keagamaan Kontemporer", Makalah disampaikan dalam Pengajian Ramadlan Pimpinan Pusat Muhammadiyah 1432 H, Kampus Universitas Muhammadiyah Yogyakarta, 7 Ramadlan/Agustus 2011, 2. 
ngawang dan berputar-putar di atas langit, tetapi menjadi semacam kompas bagi manusia yang ada di bumi. Upaya-upaya yang dilakukan oleh pemikir kontemporer menjadikan Islam sebagai agama yang bersifat theosentris dan antroposentris sekaligus, dalam wacana ini disebut progresif ijtihâdî; subyeknya dinamakan muslim progresif dan gerakannya diberi label Islam progresif. Abdullah Saed, termasuk tokoh dan sosok yang banyak berkiprah di dalamnya.

Dalam konteks kebekuan ini, Abdullah Saeed menawarkan apa yang disebut "fresh ijtihad" yang didedikasikannya untuk menjembatai keterbelakangan "cara berpikir" dan "analisis keilmuan" yang dikembangkan ilmu-ilmu agama dalam menjawab problem modernitas dan kebutuhan kontemporer. Kegelisahan akademik Abdullah Saeed tampak dalam dua hal;19

Pertama, al-Qur'an maupun hadits yang diturunkan pada masyarakat muslim abad ke-14, seringkali dikonsumsi dan diinterpretasikan oleh masyarakat muslim abad ke-21 secara literalistekstualis, sehingga konsekuensinya sering terjadi gap dan sekat yang begitu jauh antara problem wacana keagamaan dari dua generasi yang berbeda tersebut. Sekat-sekat tersebut pada akhirnya menjadikan Islam tidak lagi sebagai agama yang shâlih fi kulli zaman wa makân.

Kedua, Abdullah Saeed melihat adanya fenomena rasa phobia yang sangat mendalam di kalangan masyarakat muslim saat ini untuk merujuk dan berkonsultasi langsung pada al-Qur`an dan hadits. Hal ini disebabkan dalam diri mereka sudah terjadi doktrinisasi bahwa produk pemikiran ulama masa lampau, terutama dalam bidang fiqih sudah final. Adanya doktrinisasi tersebut tentu memberikan efek yang begitu tragis ketika dihadapkan dengan persoalan-persoalan baru, sehingga seringkali hasil keputusan hukumya bersifat rigid dan kaku, bahkan terkadang tidak manusiawi.

Melihat dua fenomena di atas, Abdullah Saeed menawarkan model pendekatan baru dalam menghadapi problem keagamaan yang disebut dengan contextualist approach (pendekatan kontekstual). Tawaran pendekatan tersebut tentu harus memperhatikan sociohistorical context di mana al-Qur`an diturunkan pada masa awal Islam

19 Abdullah Saeed, Interpreting the Qur: Towards a Contemporary Approach, (Oxon: Routledge, 2006), 1 dan 146. 
dan kebutuhan masyarakat muslim di era abad ke-21 dan masa yang akan datang. Pendekataan ini diharapkan dapat melepaskan tali jeratan umat Islam dari legalistic-literalistic approach (pendekatan tekstual legal) yang mendominasi interpretasi tafsir dan fiqh sejak periode pembentukan hukum Islam sampai era modern saat ini. ${ }^{20}$

Tawaran pendekatan Saeed di atas, sekali lagi dalam rangka membuka jeratan tali pemikiran yang rigid dan kaku. Sebab, sejatinya dalam diri mereka muncul suatu kesadaran bahwa fiqh itu merupakan hasil produk penalaran. Kata kunci definsi fiqh sebagai almuktasab (sesuatu yang didapatkan dengan usaha) mestinya menjadi key word bahwa fiqh itu lahir melalui serangkaian proses penalaran dan kerja intelektual yang panjang sebelum pada akhirnya dinyatakan sebagai hukum praktis (al-'amaliyyah). Produk fiqh tidak hanya hasil dari produk penalaran intelektual berdasarkan logikalogika keilmuan tertentu, tetapi lebih jauh merupakan bagian dari kerja ilmiah, ${ }^{21}$ sehingga perlu didialektikakan dengan kondisi yang dihadapinya.

\section{Interkonektif sebagai Epistemologi Gerakan dan Konsep Dasar Abdullah Saeed}

Islam progresif, menurut Abdullah Saeed bukanlah sebuah gerakan melainkan tren pemikiran dengan berbagai suara yang ada di dalamnya; Islam modernis, liberal, feminis atau bahkan para muslim tradisionalis yang telah bertransformasi. Lebih jauh, Islam progresif adalah salah-satu tren pemikiran Islam kontemporer yang senantiasa melakukan kontekstualisasi terhadap teks sesuai kondisi dan berkehendak untuk menjawab persoalan dan kebutuhan manusia sekaligus bercita-cita ingin mewujudkan slogan "al-Islâm shâlih li kulli zaman wa makân". Epistimologi keilmuannya adalah mendialogkan antara cara berpikir dan analisis ilmu-ilmu agama ("ulûm al-dîn) dengan ilmu-ilmu sosial modern.

Namun demikian, untuk melihat posisi muslim progresif dalam tren pemikiran muslim saat ini, Abdullah Saeed, menjelaskan

${ }^{20}$ Achmad Zaini, “Model Interpretasi al-Qur`an Abdullah Saeed”, Jurnal Islamica, Vol. 6, No. 1, (September 2011), 164.

21 Sahal Mahfudh, "Bathsul Masail dan Instibath Hukum NU; Sebuah Catatan Pendek", dalam Ahkam al-Fuqaha'; Solusi Problematika Aktual Hukum Islam (Surabaya: Khalista, 2011), x-iv 
dengan gamblang enam jenis kelompok pemikir muslim era sekarang yang corak keagamaannya berikut epistemologinya berbeda-beda: Pertama, pemikir tradisionalis (the legalist-traditionalist). Konsentrasi kelompok pemikir ini adalah pada hukum-hukum yang dikembangkan dan ditafsirkan oleh para ulama periode pra modern. Kedua, pemikir puritan (the theological puritans). Berbeda dengan pemikir sebelumnya, pada kelompok ini yang menjadi fokus pemikirannya adalah pada dimensi etika dan doktrin Islam. Ketiga, pemikir politis Islamis (the political Islamists), yang kecenderungan pemikirannya adalah pada aspek politik Islam dengan tujuan akhir mendirikan negara Islam. Keempat, pemikir Islam ekstrim (the Islamist extremists), yang memiliki kecenderungan menggunakan cara-cara anarkis untuk melawan setiap individu dan kelompok yang dianggapnya sebagai lawan baik muslim ataupun non-muslim. Kelima, pemikir sekuler (the secular muslims), yang beranggapan bahwa agama merupakan urusan pribadi (private matter) dalam tiap dinamika kehidupan. Keenam, pemikir progresif (the progressive ijtihadists), yaitu para pemikir kontemporer yang melakukan ijtihad dengan cara mereinterpretasi ajaran agama agar bisa menjawab kebutuhan masyarakat kontemporer yang semakin dinamis. Dari keenam kategori di atas, muslim progresif yang digagas Abdullah Saeed menempati posisi yang terakhir. ${ }^{22}$

\section{Tabel Pemetaan Trend Pemikiran Islam}

\begin{tabular}{|l|l|l|l|}
\hline No & Trend Pemikiran & Epistemologi & Tujuan \\
\hline 01 & $\begin{array}{l}\text { The Legalist- } \\
\text { Tradisionalist }\end{array}$ & $\begin{array}{l}\text { Hukum-hukum yang } \\
\text { dikembangkan dan } \\
\text { ditafsirkan oleh para } \\
\text { ulama pra-modern }\end{array}$ & $\begin{array}{l}\text { Untuk } \\
\text { menemukan } \\
\text { Islam otentik } \\
\text { seperti generasi } \\
\text { awal }\end{array}$ \\
\hline 02 & $\begin{array}{l}\text { The Theological- } \\
\text { Puritans }\end{array}$ & $\begin{array}{l}\text { Dimensi etika dan } \\
\text { doktrin Islam }\end{array}$ & Kepuasan Batin \\
\hline 03 & The Political-Islamists & Aspek politik Islam & $\begin{array}{l}\text { Mendirikan } \\
\text { negara Islam }\end{array}$ \\
\hline 04 & The Islamist-Extrimists & Cara-cara anarkis & $\begin{array}{l}\text { Melawan setiap } \\
\text { individu dan }\end{array}$ \\
\hline
\end{tabular}

22 Abdullah Saeed, Islamic Thought An Introduction, (London and New York: Routledge, 2006), 142-150. 


\begin{tabular}{|l|l|l|l|}
\hline 0 & & & $\begin{array}{l}\text { kelompok yang } \\
\text { berseberangan } \\
\text { dan dianggap } \\
\text { sebagai lawan } \\
\text { baik muslim } \\
\text { ataupun non- } \\
\text { muslim }\end{array}$ \\
\hline 05 & The Secular-Muslims & $\begin{array}{l}\text { Agama merupakan } \\
\text { urusan pribadi } \\
\text { (private matter) dalam } \\
\text { setiap dinamika } \\
\text { kehidupan }\end{array}$ & $\begin{array}{l}\text { Tujuannya untuk } \\
\text { memudahkan } \\
\text { setiap tindakan } \\
\text { yang berkaitan } \\
\text { dengan persoalan } \\
\text { publik, bukan } \\
\text { persoalan privat }\end{array}$ \\
\hline 06 & $\begin{array}{l}\text { The Progressive- } \\
\text { Ijtihadists }\end{array}$ & $\begin{array}{l}\text { Melakukan ijtihad } \\
\text { dengan cara } \\
\text { reinterpretasi ajaran } \\
\text { agama }\end{array}$ & $\begin{array}{l}\text { Mengakomodir } \\
\text { dan menjawab } \\
\text { kebutuhan dan } \\
\text { problem } \\
\text { masyarakat } \\
\text { kontemporer }\end{array}$ \\
\hline
\end{tabular}

Dengan demikian, muslim progresif adalah seseorang atau kelompok yang meyakini, bahwa perubahan sosial-keagamaan (socialreligious change) dan dinamika hidup kontemporer tidak akan menemukan solusi jika metodologi yang digunakan adalah piranti ushûlî paradigma lama, tanpa mengintegrasikan dengan disiplin keilmuan kontemporer. Hal ini disebabkan, problem hidup yang dihadapi muslim kontemporer jelas-jelas berbeda dengan problem yang dihadapi muslim masa lampau.

Itulah sebabnya, mengapa seorang pemikir kontemporer sekaliber Muhammad Syahrur selalu mengkritik model berpikir orang-orang salafiyah yang selalu mengandalkan, bahkan tidak berkuasa bergeser sedikitpun dari mainstream pemikiran ortodoks. ${ }^{23}$ Padahal sejatinya, menjadi muslim kontemporer harus mampu "mengamputasi" beban psikologis-teologis produk generasi masa lampau dan tidak perlu selalu mengandalkan kaca mata mereka dalam setiap menyelesaikan masalah yang dihadapinya. Sebab jika

23 Muhammad Syahrûr, al-Kitâb wa al-Qur'an'ân; Qirâ'ah Mu'âshirah, (Damaskus: Ahalli li al-Nasyr wa al-Tawzi', 1992), 46-47. 
problem hidup kontemporer selalu diselesaikan dengan merujuk pada "produk" unggulan dan andalan masa lampau, tanpa dikawinkan dengan piranti keilmuan modern, maka sikap semacam ini tidak saja membawa ummat Islam mundur, tetapi juga akan mengakibatkan stagnasi pemikiran, bahkan yang fatalis sekali akan terjadilah apa yang disebut sebagai taqdîs al-fikr dan berakhir pada sikap takfir al-fikr.

Muslim progresif yang disinyalir oleh Abdullah Saeed adalah muslim kontemporer yang dapat menyelesaikan persoalan hidupnya dengan menggunakan metodoloogi keilmuan kontemporer sekaligus melakukan reinterpretasi terhadap nash-nash atau konstruksi pemikiran muslim masa lampau. Dalam konteks ini pula, Abdullah Saeed menjelaskan secara detail karakteristik muslim progresifijtihadis, seperti berikut ini; Pertama, Mereka mengadopsi pandangan bahwa beberapa bidang hukum Islam tradisional memerlukan perubahan dan reformasi substansial dalam rangka menyesuaikan dengan kebutuhan masyarakat muslim saat ini. Kedua, Mereka cenderung mendukung perlunya fresh ijtihad dan metodologi baru dalam ijtihad untuk menjawab permasalahan kontemporer. Ketiga, Beberapa di antara mereka juga mengkombinasikan kesarjanaan Islam tradisional dengan pemikiran dan pendidikan Barat modern. Keempat, Mereka secara teguh berkeyakinan bahwa perubahan sosial, baik pada ranah intelektual, moral, hukum, ekonomi atau teknologi, harus direfleksikan dalam hukum Islam. Kelima, Mereka tidak mengikatkan dirinya pada dogmatisme atau madhhab hukum dan teologi tertentu dalam pendekatan kajiannya. Keenam, Mereka meletakkan titik tekan pemikirannya pada keadilan sosial, keadilan gender, hak asasi manusia (HAM) dan relasi yang harmonis antara muslim dan non-muslim. ${ }^{24}$

Dari enam karakteristik di atas, Saeed sebenarnya ingin menegaskan bahwa perangkat keilmuan model lama yang telah diwariskan oleh generasi awal tidak bisa menjadi "obat penawar" yang dapat menuntaskan masalah yang dihadapi muslim kontemporer, kecuali diintegrasikan dan dikawinkan dengan perangkat dan disiplin keilmuan modern. Model keilmuan lama yang dimaksudkan di sini, sebagaimana gagasan Amin Abdulllah adalah

24 Saeed, Islamic Thought, 150-151. 
disiplin keilmuan yang disebut 'ulûm al-dîn yang nota bene harus diintegrasikan dengan al-fikr al-Islâmî dan dirâsah Islâmiyyah. ${ }^{25}$

Salah-satu alasan yang dapat dijadikan indikasi pernyataan Saeed bahwa muslim progresif harus dapat mengintegrasikan disiplin keilmuan kontemporer yaitu pada poin ketiga yang menyatakan bahwa mereka juga mengkombinasikan kesarjanaan Islam tradisional dengan pemikiran dan pendidikan Barat modern. Dalam konteks ini, sebagaimana disampaikan oleh Amin Abdullah, bahwa penggunaan metode kesarjanaan dan epistemologi tradisional masih ada, di mana nash-nash al-Qur`an menjadi titik sentral berangkatnya. Akan tetapi metode penafsirannya telah didialogkan, dikawinkan dan diintegrasikan dengan penggunaan epistemologi baru, yang melibatkan social sciences dan humanities kontemporer serta filsafat kritis (critical philosophy).

Abdullah Saeed memang tidak menyebut penggunaan metode dan pendekatan tersebut secara eksplisit, tetapi pencantuman dan penggunaaan istilah "pendidikan Barat modern" adalah salah satu indikasi pintu masuk yang dapat mengantarkan para pecinta studi Islam kontemporer ke arah yang dimaksud. Juga isu-isu dan persoalan-persoalan humanities kontemporer terlihat nyata ketika Saeed menyebut keadilan sosial, lebih-lebih keadilan gender, HAM, dan hubungan yang harmonis antara muslim dan non-muslim. Persoalan humanisme kontemporer tidak akan dapat dipahami dan disimpulkan dengan baik, jika epistemologi keilmuan Islam masih menggunakan metode dan pendekatan 'ulûm al-dîn, tanpa melihat pada al-fikr al-Islâmî dan dirâsah Islâmiyyah.

Dalam Epilogue, bab 12, Abdullah Saeed menjelaskan pandangan dan kritiknya terhadap ilmu-ilmu syari'ah (lama), yang terdiri dari hadist, ushul al-fiqh dan tafsir jika hanya berhenti dan puas dengan menggunakan metode, cara kerja dan paradigma yang lama. Di bidang tafsir, dia mengajukan metode alternatif untuk dapat memahami teks-teks kitab suci sesuai dengan perkembangan dan tuntutan tingkat pendidikan umat manusia era sekarang ini. Tampak jelas bahwa Abdullah Saeed meneruskan dan mengembangkan lebih

\footnotetext{
25 M. Amin Abdullah, "Mempertautkan Ulum al-Din, al-Fikr al-Islamiy dan Dirasat Islamiyyah; Sumbangan Keilmuan Islam untuk Peradaban Global" dalam http://aminabd.wordpress.com. (Diakses pada tanggal 25 Nopember 2015).
} 
lanjut metode tafsir al-Qur`an, yang bernuansa hermeneutis, dari pendahulunya Fazlur Rahman. ${ }^{26}$

Tabel Perbedaan Epistemologi Keilmuan Islam

\begin{tabular}{|l|l|l|l|}
\hline \multicolumn{1}{|c|}{ Epistemologi } & Ulum al-Din & $\begin{array}{c}\text { Al-Fikr al- } \\
\text { Islamiy }\end{array}$ & \multicolumn{1}{|c|}{$\begin{array}{c}\text { Dirasat } \\
\text { Islamiyyah }\end{array}$} \\
\hline $\begin{array}{l}\text { Body } \text { Knowledge } \\
\text { Of }\end{array}$ & $\begin{array}{l}\text { Aqidah, } \\
\text { Syariah, Fiqih } \\
\text { dan Tafsir }\end{array}$ & $\begin{array}{l}\text { Sejarah } \\
\text { pemikiran } \\
\text { disiplin } \\
\text { keilmuan } \\
\text { secara utuh }\end{array}$ & $\begin{array}{l}\text { Penelitian Utuh, } \\
\text { serta pengamatan } \\
\text { historis-empiris }\end{array}$ \\
\hline Basis & $\begin{array}{l}\text { Bahasa dan } \\
\text { Teks }\end{array}$ & Rasio-Intelek & $\begin{array}{l}\text { Rasio dan } \\
\text { Pengalaman }\end{array}$ \\
\hline Peran Akal & Pastisipatif & Justifikatif & Legitimatif \\
\hline Pendekatan & Ilmu Bahasa & Ilmu Sejarah & $\begin{array}{l}\text { Ilmu psikologis, } \\
\text { Ilmu antropologis } \\
\text { atau ilmu } \\
\text { sosiologis }\end{array}$ \\
\hline
\end{tabular}

Konteks Historis sebagai Kerangka Teori Pemikiran Abdullah Saeed

Berkaitan dengan langkah operasionalisasi ijtihad yang dilakukan oleh muslim progresif ini, perlu dikemukakan bentukbentuk ijtihad yang populer digunakan pada periode modern ini. Artinya, dalam konteks ini, Abdullah Saeed terlebih dahulu melakukan pemetaan terhadap model ijtihad dalam bidang hukum Islam secara khusus. Setidaknya, Saeed menemukan ada 3 model ijtihad yang menurutnya sangat berpengaruh pada masanya masingmasing sepanjang sejarah hukum Islam, yaitu;

Pertama, adalah text-based ijtihad, yakni metode ijtihad yang lazim dilakukan oleh fuqahâ' klasik dan masih memiliki banyak pengaruh di kalangan pemikir tradisionalis. Pada model ini teks berkuasa penuh, baik itu nash Qur'ânî, Hadits ataupun pendapat ulama sebelumnya. Baik itu yang berupa ijmak ataupun qiyas. Kedua, adalah eclectic ijtihad, yakni upaya memilihi nash atau pendapat ulama sebelumnya yang paling mendukung pendapat dan posisi yang diyakininya. Yang ada adalah upaya justifikasi bukan pencarian

${ }^{26}$ Abdullah, Reaktulisasi Islam, 10. 
kebenaran. Ketiga, adalah context-based ijtihad, sebuah fenomena baru yang mencoba memahami masalah-masalah hukum dalam konteks kesejarahan dan konteks kekiniannya (modern). Pada biasanya, pendapat akhirnya akan mengacu pada kemaslahatan umum sebagai maqasid al-syari'ah. ${ }^{27}$

Ijtihad model ketiga inilah yang dilakukan oleh para progressive ijtihadists. Metodologi klasik biasanya memecahkan permasalahan hukum dengan mendasarkannya pada teks alQur`an, kemudian memahami apa yang dikatakan teks tentang permasalahan tersebut, dan paling jauhnya kemudian menghubungkan teks itu dengan konteks sosio-historisnya. Sedangkan pemikir progressif mencoba lebih jauh lagi menghubungkannya dengan konteks kekinian sehingga tetap up to date dan bisa diterapkan. Inilah sesungguhnya yang dilakukan oleh, antara lain Muqtader Khan, Thariq Ramadlan, Bassam Tibi, Aminah Wadud, Farid Esack, Irshad Manji, dan Ebrahim Moosa.

Berkaitan dengan metodologi progressive ijtihadists dalam menafsir ulang teks-teks al-Qur`an, Abdullah Saeed memaparkan tujuh pendekatan utama;28 Pertama, atensi pada konteks dan dinamika sosio-historis. Kedua, menyadari bahwa ada beberapa topik yang tidak dicakup dan tidak dikaver oleh al-Qur'an karena waktunya belum tiba pada waktu diturunkannya al-Qur`an. Ketiga, menyadari bahwa setiap pembacaan atas teks kitab suci harus dipandu oleh prinsip kasih saying; justice dan fairness. Keempat, mengetahui bahwa al-Qur`an mengenal hirarki nilai-nilai dan prinsip. Kelima, mengetahui bahwa dibolehkan berpindah dari satu contoh yang kongkrit pada generalisasi atau sebaliknya. Keenam, kehati-hatian harus dilakukan ketika menggunakan teks lain dari tradisi klasik, khususnya yang berkaitan dengan otentisitasnya. Ketujuh, fokus utama pada kebutuhan muslim kontemporer.

Dari ketujuh pendekatan di atas, ada beberapa hal yang perlu diperhatikan ketika Abdullah Saeed menyebut konteks dinamika sosio-historis dan pembacaan kitab suci harus dipandu oleh prinsip kasih sayang, justice dan fairness, maka kedua hal tersebut sebenarnya mengindikasikan keterpengaruhannya pada metodologi

\footnotetext{
27 Saeed, Islamic Thought, 55.

28 Mawardi, Islam Progresif, 537.
} 
yang ditawarkan oleh Fazlurrahman dan Khalid Abou el-Fadl. Hal ini dikarenakan dalam bukunya yang berjudul Interpreting The Qur, Saeed dengan mantap mengakuinya bahwa kedua tokoh tersebut telah memberikan kontribusi besar dalam penafsiran ayat-ayat ethico-legal-nya. ${ }^{29}$ Terutama dalam konteks penafsiran ethico-legal, Saeed mengaku lebih banyak terinspirasi -untuk tidak mengatakan mengadopsi- dari Rahman. Keterpengaruhan Saeed begitu kentara dalam bangunan pemikirannya. Karena itu, di samping sebagai seorang Rahmanian, ia juga dianggap meneruskan dan menyempurnakan metodologi tafsir Rahman.

Adapun hierarki nilai dalam al-Qur’an yang dimaksudkan oleh Saeed, sebagaimana pendekatan yang disebutkan dalam item keempat, ia menegaskan terdapat lima hierarki; Pertama, nilai yang bersifat kewajiban. Nilai ini tidak akan berubah mengikuti perubahan kondisi, tetapi tetap menjadi doktrin tetap, seperti nilai yang berhubungan dengan sistem teologi, praktik ibadah dan halalharam. Kedua, nilai fundamental yaitu nilai kemanusiaan dasar yang disebut dengan hifzd al-mâl, hifzd al-nasl, hifzd al-dîn, hifzd al-nafs, dan hihzd al-'aql. Ketiga, nilai proteksional yang berfungsi untuk menjaga keberlangsungan nilai fundamental. Keempat, nilai implementasional yang berfungsi untuk merealisasikan nilai proteksional. Kelima, nilai instruksional yaitu nilai ukuran atau tindakan yang terdapat dalam al-Qur`an tentang sebuah persoalan yang berlaku khusus pada masa pewahyuan. ${ }^{30}$

\section{Model Kasus dan Posisi Abdullah Saeed dengan Penggiat Keislaman Lainnya}

Salah satu contoh kasus yang menarik dari pemikiran Abdullah Saeed adalah tentang larangan riba. Sebagaimana diketahui bersama, bahwa kata riba ${ }^{31}$ dalam al-Qur`an ditemukan terulang

\footnotetext{
29 Abdullah Saeed, Interpreting The Qur; Towards a Contemporary Approach (London and New York: Routledge, 2006), 5-6.

30 Ibid., 130.

31 Kata al-ribâ berasal dari kata rabawa yang berarti bertambah. Kata rabat yang disebutkan dalam Q.S al-Hajj 22:5 bermakna irtafa'at, namat, dan zadat yang berarti bertambah. Kata rabiyatan dalam Q.S al-Haqqah 69:10 bermakna namiyatan yang berarti "bertambah besar". Demikian pula kata al-ribâ yang termaktub dalam Q.S alBaqarah 2:267 juga bermakna bertambah. Artinya, kata al-riba adalah perilaku pemilik
} 
sebanyak delapan kali, 32 terdapat dalam empat surat, yaitu al-Baqarah (275, 276, 278), Ali 'Imran (130), al-Nisa' (159), dan al-Rum (39). Tiga surat pertama adalah "Madaniyyah" (turun pasca Nabi hijrah ke Madinah), sedang surat al-Rum adalah "Makkiyyah" (turun pra hijrah ke Madinah).

Wacana tentang pelarangan riba tentu saja merupakan wacana klasik, tetapi tidak pernah usang untuk didiskusikan dan diperdebatkan. Status hukum bunga riba yang terjadi di bank-bank konvensional menuai kontroversi antara kelompok yang pro pelarangan praktik bunga bank konvensional dengan kelompok kontra yang melegalkannya. Kelompok yang pro pelarangan praktik bunga bank direpresentasikan oleh ulama-ulama klasik, termasuk di dalamnya, pemikir Islam modern Yusuf al-Qardlawi.

Menurut al-Qardlawi, bahwa Islam secara tegas telah mengharamkan riba dan secara keras melarangnya. Pengharaman dan pelarangan itu telah final, berdasarkan hukum dari nash-nash yang pasti (qath'î) di dalam al-Qur`an dan Sunnah, sehingga tidak ada lagi ruang yang bersifat reinterpretatif dengan alasan ijtihad dan pembaharuan hukum (tajdîd). ${ }^{33}$ Finalisasi praktik bunga bank tersebut berdasarkan fase-fase pelarangan yang ada dalam al-Qur`an, yang menurut Mustafa al-Maraghi, ${ }^{34}$ menjadi empat fase, yaitu; Pertama, fase sebatas mendeskripsikan adanya unsur negatif di dalamnya ${ }^{35}$. Kedua, fase isyarat tentang keharamannya ${ }^{36}$. Ketiga, fase yang secara eksplisit dinyatakan keharaman salah satu bentuknya ${ }^{37}$. Keempat, fase diharamkan secara totalitas dalam berbagai bentuknya. ${ }^{38}$

modal yang mengambil keuntungan dari peminjam modal. Kata arba-yurbi berarti mengambil lebih banyak dari yang diberikan. Lihat selengkapnya dalam al-Tunji, $\mathrm{Al}$ Mu'jam al-Mufassal fi al-Tafsir al-Qur'an al-Karim, (Beirut: Dar al-Kutub al-Ilmiyyah, 1424), 190.

32 al-Maqdisi, Fath al-Rahman li Talibi Ayat al-Qur'an, (Jakarta: Diponegoro, t.th.), 171.

33 Yusuf Al-Qardlawi, Fawaid al-Bunuk hiya al-Riba al-Haram, Cet I, (Kairo: Dar Shahwah, 1990), 14.

34 Ahmad Musthafâ al-Marâghî, Tafsîr al-Marâghî, Vol. III, (Mesir: Musthafâ al-Halabi, 1946), 59

${ }^{35}$ Al-Qur'an Surat al-Rûm (30): 39

36 Al-Qur'an Surat al-Nisâ' (4):159

37 Al-Qur'an Surat Ali 'Imrân (3):130

38 Al-Qur'an Surat al-Baqarah (2): 278 
Berbeda dengan kelompok pro-pelarangan praktik riba, Abdullah Saeed termasuk sosok intelektual muslim yang berani dengan lantang menyuarakan legalisasi praktik bunga bank konvensional. Menurutnya, dalam memahami tentang ayat-ayat riba, diperlukan mapping terhadap kebutuhan pinjaman yang dilakukan debitur kepada kreditur, bahwa ada debitur yang pola dan tujuan pinjamannya bersifat produktif, serta ada pula yang bersifat konsumtif. Pemetaan tersebut akan memberikan solusi tersendiri terhadap kebutuhan para debitur produktif dalam mengelola dan membangun kerajaan bisnisnya.

Dengan menggunakan teori socio-historical context, lebih lanjut ia menyatakan, bahwa semua ayat-ayat al-Qur`an yang berbicara pelarangan riba, hanya ditujukan kepada kreditur yang memberikan pinjaman kepada debitur yang bersifat konsumtif demi menutupi kebutuhan primernya. Karena itu, penyebutan kata riba dalam alQur'an yang sering bergandengan dengan kata shadaqah dan zakat ${ }^{39}$ sebagai indikasi konkrit tentang pembelaan al-Qur`an kepada orangorang lemah. Fenomena ini tentu merupakan entry point bahwa alQur`an memberikan perhatian yang mendalam terhadap masyarakat yang secara ekonomi lemah dan menekankan untuk membantu kebutuhan finansial mereka, dengan catatan tanpa memberi tambahan beban penderitaan. Di sini terlihat bahwa, tidak ada indikasi bahwa tuntunan ini berlaku terhadap kasus pinjaman bagi orang-orang kaya yang digunakan untuk tujuan perdagangan dan bidang komersial lainnya. ${ }^{40}$

Berdasarkan kasus dan fenomena di atas, dengan memperhatikan socio-historical context, Abdullah Saeed menegaskan, bahwa dalam praktiknya, sistem bunga dalam perbankan konvensional saat ini, yang diberikan pihak kreditur kepada debitur produktif tidaklah termasuk ke dalam jenis bunga yang menyebabkan

\footnotetext{
${ }^{39}$ Lihat misalnya, Q.S al-Baqarah 2:276 yang menyatakan bahwa, "Allah memusnahkan riba dan menyuburkan sedekah", serta Q.S. al-Rûm 30:39 yang menyatakan bahwa, "dan sesuatu riba (tambahan) yang kamu berikan agar dia bertambah pada harta manusia, maka riba itu tidak menambah pada sisi Allah, dan apa yang kamu berikan berupa zakat yang kamu maksudkan untuk mencapai keridhaan Allah, maka (yang berbuat demikian) Itulah orangorang yang melipat gandakan (pahalanya)".

40 Abdullah Saeed, Islamic Banking and Interest: A Study of the Prohibition of Riba and its Contemporary Interpretation, (EJ Brill, 2001), 37-39.
} 
terjadinya ketidakadilan, apalagi sampai pada terjadinya penindasan dan penganiayaan yang dilakukan oleh kreditur kepada debitur. Oleh sebab itu, bunga bank yang demikian bukanlah termasuk ke dalam riba yang dilarang, sebab tidak menimbulkan efek buruk, yang menjadi tujuan utama dalam aspek pelarangan riba dalam Islam. ${ }^{41}$ Sebab bunga bank memiliki manfaat yang besar dalam mendorong tercapainya kemajuan suatu masyarakat, bahkan transaksi pinjammeminjam dalam sistem perbankan dilakukan secara jelas, terbuka dan dilindungi oleh undang-undang, sehingga tidak memungkinkan terjadinya penindasan oleh kreditur terhadap debitur ${ }^{42}$ yang dalam al-Qur`an disebut lâ tudzlimûna wa lâ tudzlamûn.

Pemikiran Abdullah Saeed tentang legislasi bunga bank konvensional, ternyata tidak jauh berbeda dengan ide dan gagasan yang pernal dilontarkan oleh pemikir modernis laiinya, semisal Fazlurrahman yang lebih menekankan aspek kontekstual antara pinjaman pada masa jahiliyah dengan masa kini yang sudah berbeda konteks penerapannya. Demikian juga, pandangan Saeed juga mirip dengan gagasan yang diusung oleh Rashid Ridha dan Muhammad Abduh yang memandang bahwa sistem perbankan saat ini mirip dengan sistem perkongsian dalam Islam, dan lembaga perbankan menjadi kebutuhan yang sangat vital, sebagai media bagi tercapainya kemajuan dalam suatu masyarakat.

\section{Kesimpulan}

Menjadi muslim kontemporer harus mampu mengatasi beban psikologis-teologis produk generasi masa lampau dan tidak selalu mengandalkan pandangan mereka dalam menyelesaikan masalah yang dihadapi. Sebab jika problem hidup kontemporer selalu diselesaikan dengan merujuk pada "produk" unggulan dan andalan masa lampau, tanpa diperkaya dengan piranti keilmuan modern, maka sikap semacam ini tidak saja membawa mundur umat Islam, tetapi juga akan mengakibatkan stagnasi pemikiran, bahkan yang fatalis sekali akan terjadilah apa yang disebut sebagai taqdîs al-fikr dan berakhir pada sikap takfîr al-fikr.

\footnotetext{
41 Ibid., 75.

42 Ibid., 51-52.
} 
Dengan gagasan Islam progresif-nya, Abdullah Saeed menawarkan pendekatan baru diakibatkan perkembangan sosial, ekonomi, politik, kedokteran dan astronomi, human rights, dan gender yang begitu pesat dan umat Islam membutuhkan pegangan yang berbasis pada al-Qur`an. Pendekatan baru tersebut disebut dengan contextualist approach yang memperhatikan socio-historical context dengan harapan umat Islam dapat memahami legalistic-literalistic approach yang mendominasi interpretasi tafsir dan fiqh sejak periode pembentukan hukum Islam sampai era modern saat ini.

Adapun metodologi yang digunakan Abdullah Saeed dalam menafsir ulang teks-teks al-Qur`an, ada tujuh pendekatan utama; Pertama, atensi pada konteks dan dinamika sosio-historis. Kedua, menyadari bahwa ada beberapa topik yang tidak dicakup dan tidak dibahas oleh al-Qur`an karena waktunya belum tiba pada waktu diturunkannya al-Qur`an. Ketiga, menyadari bahwa setiap pembacaan atas teks kitab suci harus dipandu oleh prinsip keadilan dan kejujuran (justice and fairness). Keempat, mengetahui bahwa alQur`an mengenal hirarki nilai-nilai dan prinsip. Kelima, mengetahui bahwa dibolehkan berpindah dari satu contoh yang konkrit pada generalisasi atau sebaliknya. Keenam, kehati-hatian harus dilakukan ketika menggunakan teks lain dari tradisi klasik, khususnya yang berkaitan dengan otentisitasnya. Ketujuh, fokus utama pada kebutuhan muslim kontemporer.

\section{Daftar Pustaka}

Abdurrahman, Moeslim. Islam Tranformatif. Jakarta: Pustaka Firdaus, 1997.

Abdullah, M. Amin. Reaktulisasi Islam yang Berkemajuan; Agenda Strategis Muhammadiyah Ditengah Gerakan Keagamaan Kontemporer, Makalah disampaikan dalam Pengajian Ramadlan Pimpinan Pusat Muhammadiyah 1432 H, Kampus Universitas Muhammadiyah Yogyakarta, 7 Ramadlan/Agustus 2011.

--------. "Mempertautkan Ulum al-Din, al-Fikr al-Islamiy dan Dirasat Islamiyyah; Sumbangan Keilmuan Islam untuk Peradaban Global" dalam http://aminabd.wordpress.com. Diakses pada tanggal, 25 Nopember 2015. 
Ali, Fachry dan Effendy, Bahtiar. Merambah Jalan Baru Islam, Rekonstruksi Pemikiran Islam Masa Orde Baru. Bandung: Mizan, 1986.

Maqdisi al-, Fath al-Rahman li Talibi Âyat al-Qur'ân. Jakarta: Diponegoro, t.th.

Marâghî, Ahmad Musthafâ al-. Tafsîr al-Marâghî, Vol. III. Mesir: Mustafa Al-Halabi, 1946.

Qardlawi, Yusuf al-. Fawâ'id al-Bunûk Hiya al-Ribâ al-Haram, Cet I. Kairo: Dar Shahwah, 1990.

Tunji al-, Al-Mu'jam al-Mufassal fi al-Tafsîr al-Qur'ân al-Karîm. Beirut: Dar al-Kutub al-Ilmiyyah, 1424.

Anwar, M. Syafi'i. Pemikiran dan Aksi Islam Indonesia, sebuah Kajian tentang Cendikiawan Muslim Orde Baru. Jakarta: Paramadina, 1995.

Barton, Greg. Gagasan Islam Liberal di Indonesia. Jakarta: Pustaka Antara, 1999.

Fiderspiel, Howar M. Persatuan Islam, Pembaruan Islam Indonesia Abad XX. Yogyakarta: Gadjah Mada University Press, 1996.

Goldziher, Ignaz. Mazhâhib al-Tafsîr al-Islâmî. Mesir: Maktabah alKhaniji, 1955.

Houroni, G. F. Reason and Tradition in Islamic Ethic. Cambridge: University Press Cambridge, 1985.

Mahfudh, Sahal "Bathsul Masail dan Instibath Hukum NU; Sebuah Catatan Pendek", dalam Ahkam al-Fuqaha'; Solusi Problematika Aktual Hukum Islam. Surabaya: Khalista, 2011.

Mawardi, Ahmad Imam. "Muslim Progresif dan Ijtihadi Progresif dalam Pandangan Abdullah Saeed", dalam Tolhatul Choir, Islam dalam Berbagai Pembacaan Kontemporer. Yogyakarta: Pustaka Pelajar, 2009.

Noer, Deliar. Gerakan Modern Islam di Indonesia 1900-1942. Jakarta: LP3ES, 1996.

Noor, Farish A. Islam Progresif: Peluang, Tantangan, das Masa Depannya di Asia Tenggara. Terj. Moch. Nur Ichwan dan Imron Rosyadi. Yogyakarta: SAMHA, 2006.

Rahman, Fazlur. Towards an Islamic Theory of International Relations: New Direction for Methodology and Thought. Herdon, Virginia: IIT, 1993. 
Saeed, Abdullah. Interpreting The Qur'an; Towards a Contemporary Approach. London and New York: Routledge, 2006.

--------. Islamic Thought An Introduction. London and New York: Routledge, 2006.

------. Islamic Banking and Interest: A Study of the Prohibition of Riba and its Contemporary Interpretation. EJ Brill: 2001.

Shihab, Alwi. Islam Inklusif; Menuju Sikap Terbuka dalam Beragama. Bandung: Mizan, 1999.

Syamsuddin, Sahiron. Islam Progressif dan Upaya Pembumiannya di Indonesia, dalam nahdliyinbelanda.wordpress.com. Diakses pada tanggal 25 Nopember 2015.

Syahrur, Muhammad. al-Kitâb wa al-Qur`an; Qirâah Mu'âshirah. Damaskus: Ahalli li al-Nasyr wa al-Tawzi', 1992.

Zaini, Achmad. "Model Interpretasi al-Qur`an Abdullah Saeed", Jurnal Islamica, Vol. 6, No. 1. September 2011. 